This manuscript is contextually identical with the following published paper:

ÁCS É.;WETZEL C.E., HLÚBIKOVÁ D., GRIGORSZKY I., TRÁBERT Z., ECTOR

L. (2016) Morphology and distribution of Brevilinea kevei sp. nov. (Bacillariophyceae), a new diatom from Europe. PHYTOTAXA 284: (1) pp. 24-30.

http://dx.doi.org/10.11646/phytotaxa.284.1.2

The original published pdf available in this website:

http://biotaxa.org/Phytotaxa/article/view/phytotaxa.284.1.2

\title{
Morphology and distribution of Brevilinea kevei sp. nov. (Bacillariophyceae), a new diatom from Europe
}

\author{
ÉVA ÁCS ${ }^{1 *}$, CARLOS E. WETZEL ${ }^{2}$, DASA HLÚBIKOVÁ ${ }^{3}$, ISTVÁN GRIGORSZKY ${ }^{1,4}$, \\ ZSUZSA TRÁBERT ${ }^{1} \&$ LUC ECTOR ${ }^{2}$
}

${ }^{1}$ MTA Centre for Ecological Research, Danube Research Institute, 1113 Budapest, Karolina út 29, Hungary

${ }^{2}$ Environmental Research and Innovation Department (ERIN), Luxembourg Institute of Science and Technology (LIST), 41 rue du Brill, L-4422 Belvaux, Luxembourg

${ }^{3}$ DWS Hydro-Ökologie GmbH, Zentagasse 47, 1050 Wien, Austria

${ }^{4}$ University of Debrecen, Department of Hydrobiology, H-4032 Debrecen, Egyetem tér 1., Hungary

*Corresponding author (E-mail: acs.eva@okologia.mta.hu)

\begin{abstract}
An unknown small naviculoid diatom was found in the epiphyton samples from Hungary (in Kanyari Holt-Tisza oxbow) and in the epilithon samples from France (Canal de Berry at Épineuil-le-Fleuriel). The detailed observations using light and scanning electron microscopy have allowed us to describe the new species Brevilinea kevei Ács \& Ector sp. nov. It can be separated from Brevilinea pocosinensis Siver et al. (which was the only described species in the genus) by its size (smaller than B. pocosinensis), shape (elliptic valve, never capitate) and ecological requirements. Brevilinea pocosinensis lives in acidic conditions while B. kevei in neutral ones. Differential diagnostic criteria with respect to similar taxa, especially Fallacia indifferens (Hustedt) D.G. Mann, together with ecological implications of this finding are briefly discussed.
\end{abstract}

Key words: Brevilinea, taxonomy, ecology, distribution, Fallacia indifferens 


\section{Introduction}

During the Hungarian surveillance monitoring in 2011, a small, elliptical diatom was found as a codominant species with Sellaphora archibaldii (J.C. Taylor \& Lange-Bertalot 2006: 178) C.E. Wetzel, Ács \& Ector in Ács et al. (2017) in Kanyari Holt-Tisza near Kisköre, Hungary. In the same year a similar small diatom was discovered in an epilithic sample from the Canal de Berry at Épineuil-le-Fleuriel, France.

In light microscopy this species looks like Fallacia indifferens (Hustedt 1942: 67) D.G. Mann in Round et al. (1990: 668), but after the scanning electron microscopy (SEM) study we realised that its ultrastructure differs from all other known diatoms. On the basis of the relatively short, linear raphe fissure not reaching the end of the valve and the highly visible raphe-sternum, the species undoubtedly belongs to the genus Brevilinea.

The monotypic genus Brevilinea Siver, P.B. Hamilton \& E. Morales (2008: 142) was described from Pungo Lake, Creswell County, North Carolina, USA. According to these authors the most important characteristics of the genus are the reduced raphe system and the uncommonly large, square shaped areolae making the genus unique. The reduced raphe system means that the distal ends of the relatively short, linear raphe are on valve face in about of $1 / 3$ valve length from the poles. The raphe is situated within the conspicuously thickened sternum (Figs 2-4 therein). The areolae are externally opened, internally covered by hymenes. Frustules are small, isovalvar and have bilateral symmetry. The type species of the genus is Brevilinea pocosinensis Siver, P.B. Hamilton \& E. Morales (2008: 142, Figs $1-4)$.

The main objectives of this study were 1) to describe the new Brevilinea species; 2) to make comparisons with species more similar to the new taxon, especially with Fallacia indifferens, the most similar diatom when viewed with the light microscope (LM); 3) to demonstrate the world distribution of this new species and 4) to show its ecological demands. To achieve the second objective, the type material of $F$. indifferens was examined for morphological comparison with the new species.

\section{Material and method}

One sample of epiphyton from the green reed stems in the Kanyari Holt-Tisza, Hungary $\left(47.489822^{\circ} \mathrm{N}, 20.449911^{\circ} \mathrm{E}\right)$ was collected in August 2011. The Kanyari Holt- 
Tisza is an oxbow of Tisza River with alkaline, eutrophic water and high concentration of electrolytes. Its surface area is 54 ha. Average water depth is approximately $2 \mathrm{~m}$ in spring, and decreases to approximately $0.9 \mathrm{~m}$ in autumn. The coverage of the water body is about $50 \%$ with the dominance of sedge (Carex sp.) and reed (Phragmites australis (Cav.) Trin. ex Steud.). On the sampling day following environmental values were measured: water temperature $22{ }^{\circ} \mathrm{C}, \mathrm{pH} 7.8$, electric conductivity $1418 \mu \mathrm{S} \mathrm{cm}^{-1}$, TOC $12.4 \mathrm{mg} \mathrm{L}^{-1}$, DO $4.2 \mathrm{mg}$ $\mathrm{L}^{-1}, \mathrm{PO}^{4-} \mathrm{P} 91.5 \mu \mathrm{g} \mathrm{L}{ }^{-1}$, TP $520 \mu \mathrm{g} \mathrm{L}^{-1}$.

The second sample was collected in August 2011 from the Canal de Berry at Épineuille-Fleuriel, Centre-Val de Loire region, France $\left(46.557942^{\circ} \mathrm{N}, 2.584089^{\circ} \mathrm{E}\right)$. The sampling site is characterised by coloured water with slow flow. The bottom is covered by macrophytes and fine sediment. There are no data on the water chemistry available for the respective sampling occasion. This artificial eutrophic lowland channel is mainly exploited for the ship transportation and tourism.

The diatom frustules were cleaned with hydrochloric acid and hydrogen peroxide, subsequently washed in distilled water and mounted with Naphrax ${ }^{\circledR}$ medium (CEN 2014). An Olympus IX70 inverted microscope equipped with differential interference contrast (DIC) optics and a Leica DMR microscope equipped with a Leica-DFC 500 high-resolution digital camera using Leica Application Suite software (v. 3.7.0, Leica Microsystems) were used for LM observations. For EM studies a part of the cleaned and washed samples was filtered through a $3 \mu \mathrm{m}$ Isopore ${ }^{\mathrm{TM}}$ polycarbonate membrane filter (Merck Millipore), which was fixed onto a stub using double-sided carbon tape, and coated with gold using a rotarypumped spatter coater Quorum Q150R S. In the Hungarian sample, fine structures of the diatom frustules were observed with Zeiss EVO MA 10 SEM operated at $15 \mathrm{kV}$ and $10 \mathrm{~mm}$ distance using SE and STEM detectors.

French sample and type material of Navicula indifferens Hustedt (sample E1009) from the Friedrich Hustedt Collection (Alfred-Wegener-Institut, Helmholtz-Zentrum für Polar- und Meeresforschung, Bremerhaven) were investigated with an ultrahigh-resolution analytical field emission (FE) SEM Hitachi SU-70 (Hitachi High-Technologies Corporation, Japan) operated at $5 \mathrm{kV}$ and $10 \mathrm{~mm}$ distance was used for the analysis. For SEM observations the cleaned samples were filtered with additional deionized water through a 3- $\mu \mathrm{m}$ Isopore ${ }^{\mathrm{TM}}$ polycarbonate membrane filter (Merck Millipore). Filter was mounted on aluminium stub and coated with platinum using a Modular High Vacuum Coating System BAL-TEC MED 020 (BAL-TEC AG, Balzers, Liechtenstein). SEM images were taken using the lower (SE-L) and upper (SE-U) detector signal. 


\section{Results}

Brevilinea kevei Ács et Ector sp. nov. (Figs 1-30)

Description: In LM (Figs 1-20), the valves are rhombic-elliptic to oval with rounded apices. The striation is irresolvable. Practically only the raphe, the central nodule and helictoglossae are visible. Valve length 3.9-5.5 $\mu$ m (mean: $4.9 \mu \mathrm{m}$, SD: 0.33, $\mathrm{n}=26$ ), valve width 1.8-2.5 $\mu \mathrm{m}$ (mean: $2.1 \mu \mathrm{m}$, SD: 0.16, $\mathrm{n}=26$ ).

Ultrastructure based on SEM micrographs (Figs 11-28): Striae are radiate and composed of single rows of areolae. Stria density 50 in $10 \mu \mathrm{m}$, composed by 2-6 areolae/stria. Virgae are raised clearly separating striae and areolae (Fig. 25). The thickened virgae continue on the mantle (Fig. 22). Areolae are closed by hymenes, and are square in external view (Fig. 23) and round in internal view (Fig. 24). The external raphe fissure is slightly curved, the raphe-sternum is prominent (Fig. 26). The distal ends of the raphe are drop-shaped and the central raphe endings are slightly deflected to the same valve side (Fig. 22). The proximal ends of the raphe are spaced (Figs 21-22, 27). Internally, the raphe fissures are straight, terminating in small helictoglossae near the valve poles (Figs 24, 28). The valve margin is thickened (Fig. 22). TEM micrographs show the radiate striae composed of single rows; the large, square shaped areolae are clearly visible (Figs 29-30).

Holotype: Fig. 25 designed here. Type material: GO-14/11, deposited at the Centre for Ecological Research, Danube Research Institute, Budapest, Hungary, epiphyton, collected by K. Nagy on 16/08/2011. BP2260 deposited at the Hungarian Natural History Museum, Budapest, Hungary.

Type locality: Kanyari Holt-Tisza, Hungary $\left(47.489822^{\circ} \mathrm{N}, 20.449911^{\circ} \mathrm{E}\right)$.

Isotypes: Figs 26-30 designed here.

Paratypes: Figs 21-24 designed here.

Etymology: The name is chosen in honour of the famous Hungarian algologist Prof. Dr. Keve T. Kiss.

Investigation of type material of Fallacia indifferens (Hustedt) D.G. Mann

Holotype: Hasbruch. Moss üb. Wasser b. d. Hütte. 1. Forst Delmenorst in Oldenburg. 
In LM (Figs 32-41), the valves are rhombic-elliptic to oval with rounded apices. These characteristics were also drawn by Hustedt (Fig. 31; Hustedt 1942, figs 27-30). Practically only the raphe is visible. Valve length $6.5-8.0 \mu \mathrm{m}$, valve width $2.5-3.2 \mu \mathrm{m}$.

Ultrastructure based on SEM micrographs (Figs 42-45): Striae are radiate and composed of two elongated areolae (Figs 42, 44), internally covered by hymenes (Figs. 43, 45). Stria density 34-45 in $10 \mu \mathrm{m}$. In external view, lanceolate conopeum covers of approximately half valvar face (Figs 42, 44). The raphe is filiform, almost straight. The raphe-sternum is not prominent. Externally the distal raphe endings are deflected to the primary valve side and elongated onto the valve mantle (Figs 42, 44). Central raphe endings are close to each other and slightly deflected to the same valve side. Internally the raphe fissures are straight, terminating in small helictoglossae (Figs 43, 45).

\section{Distribution and ecology of Brevilinea kevei}

The new taxon occurs in eutrophic waters with high electrolyte content. The water $\mathrm{pH}$ was 7.8 at the time of sampling. When first sampled this species was recorded from an abandoned dredge pond near Bulolo, Papua New Guinea, which is alkaline water with high conductivity, however it was misidentified as Navicula saprophila Lange-Bertalot \& Bonik (Vyverman 1991: fig. 115B, outside view in SEM). New locations of B. kevei were recorded only in Europe (Fig. 46). In addition to the type locality in Hungary, we have found it in several places in France: Layon River at Saint-Lambert-du-Lattay, Region Pays de la Loire, August 2003, its relative abundance was 3.7 \%; Sanguèze River at Le Pallet, Region Pays de la Loire, June 2011, with relative abundance of $4.2 \%$; Canal de Berry at Épineuil-le-Fleuriel, Cher Basin, Region Centre-Val de Loire, August 2011, with relative abundance of $4 \%$.

\section{Discussion}

Differential diagnosis of Brevilinea kevei from B. pocosinensis: very small size (B. pocosinensis is 7-13 $\mu \mathrm{m}$ length and $2.5-3 \mu \mathrm{m}$ width) with oval valves, which are never capitate. To date, B. pocosinensis is only known from Pungo Lake, North Carolina, an acidic $(\mathrm{pH}=4.9)$, poorly buffered waterbody with a low water transparency due to the high concentration of humic-stained substances (Siver \& Hamilton 2011). Consequently $B$. pocosinensis inhabits acidic waters while $B$. kevei has been found in alkaline waters $(\mathrm{pH}=$ 7.8). 
Brevilinea kevei most resembles Navicula indifferens Hustedt described from NorthWestern Germany (Hustedt 1942: 67, figs 27-30, here Fig. 31). Navicula indifferens was transferred to the genus Fallacia - as Fallacia indifferens (Hustedt) D.G. Mann in Round et al. (1990). Brevilinea kevei differs from $F$. indifferens and other similar very small pennate diatoms morphologically, e.g. Fistulifera saprophila (Lange-Bertalot \& Bonik 1976: 312) Lange-Bertalot (1997: 73), Mayamaea atomus (Kützing 1844: 108) Lange-Bertalot (1997: 72), Mayamaea permitis (Hustedt 1945: 919) Bruder \& Medlin (2008: 327), Sellaphora bosniaca Kapetanović \& R. Jahn in Kapetanović et al. (2011: 130), even in LM on the basis of the relatively large distance between proximal raphe endings. In SEM the reduced raphe system surrounded by a prominent sternum clearly distinguishes it from the other diatoms.

In type locality $B$. kevei was dominant (its relative abundance was $14.7 \%$ ). The codominant taxa were Cyclotella meneghiniana Kützing, its relative abundance was $14.6 \%$; Amphora pediculus (Kützing) Grunow (7.8 \%), Nitzschia frustulum (Kützing) Grunow (9.1 \%) and Sellaphora archibaldii (J.C. Taylor \& Lange-Bertalot) C.E. Wetzel, Ács \& Ector (18 $\%)$. In the epilithon of the Canal de Berry the codominant taxa were Discostella pseudostelligera (Hustedt) Houk \& Klee (with relative abundance of 19.7\%), Nitzschia costei Tudesque, Rimet \& Ector (9.4\%) and Achnanthidium eutrophilum (Lange-Bertalot) LangeBertalot (7.5\%).

The ecological requirements of codominant species are also the nutrient (nitrogen and phosphorus) rich freshwaters. Nitzschia costei is an epilithic, rheophilous, alkaliphilous taxon, occurring strictly in freshwater bodies, its oxygen requirement is fairly high (above $75 \%$ saturation), beta-mesosaprobous and eutraphentic (Tudesque et al. 2008). Sellaphora archibaldii was found in alkaline, eutrophic water with elevated electrolyte content in Europe (Ács et al. 2017) and in South Africa as well (Taylor \& Lange-Bertalot 2006). Cyclotella meneghiniana, A. pediculus, N. frustulum, D. pseudostelligera and A. eutrophilum are also eutraphentic species (Van Dam et al. 1994).

We consider $B$. kevei to be more abundant then we had currently known, but it is sometimes misidentified and overlooked due to its small and thin cell.

\section{Acknowledgments}

We sincerely thank Friedel Hinz (Hustedt Collection, Alfred-Wegener-Institut, HelmholtzZentrum für Polar- und Meeresforschung, Bremerhaven) for providing us with the type material of Fallacia indifferens; Katalin Nagy (North Hungarian Inspectorate for Environmental Protection and Nature Conservation authority) for the sample from Kanyari 
Holt-Tisza, Hungary; Didier Guillard (DREAL Pays de la Loire, Nantes) for the information on the records of Brevilinea kevei in the rivers of Pays de la Loire Region, France. We thank Diba Khan-Bureau (Three Rivers Community College, Norwich) for their precious English corrections. Funding for this research was partly provided in the framework of the DIATOMS project (LIST - Luxembourg Institute of Science and Technology).

\section{References}

Ács, É., Weztel, C.E., Buczkó, K., Kiss, K.T., Nagy, K., Trábert, Zs., Földi, A., Werner, P., Heudre, D. \& Ector, L. (2017) Biogeography and morphology of a poorly known Sellaphora species. Fottea.

Bruder, K. \& Medlin, L.K. (2008) Morphological and molecular investigations of naviculoid diatoms. II. Selected genera and families. Diatom Research 23(2): 283-329. http://dx.doi.org/10.1080/0269249X.2008.9705759

CEN (2014) Water quality - guidance for the routine sampling and preparation of benthic diatoms from rivers and lakes. EN 13946: 2014. Comité Européen de Normalisation, Bruxelles. 14 pp.

Hustedt, F. (1942) Aërophile Diatomeen in der nordwestdeutschen Flora. Berichte der Deutschen Botanischen Gesellschaft 60(1): 55-73. http://dx.doi.org/10.1111/j.1438-8677.1942.tb00439.x

Hustedt, F. (1945) Diatomeen aus Seen und Quellgebieten der Balkan-Halbinsel. Archiv für Hydrobiologie 40(4): 867-973.

Kapetanović, T., Jahn, R., Redžić, S. \& Carić, M. (2011) Diatoms in a poor fen of Bijambare protected landscape, Bosnia \& Herzegovina. Nova Hedwigia 93(1-2): 125-151. http://dx.doi.org/10.1127/0029-5035/2011/0093-0125

Kützing, F.T. (1844) Die Kieselschaligen Bacillarien oder Diatomeen. W. Köhne, Nordhausen, 152 pp., 30 pls.

http://dx.doi.org/10.5962/bhl.title.64360 
Lange-Bertalot, H. (1997) Frankophila, Mayamaea und Fistulifera: drei neue Gattungen der Klasse Bacillariophyceae. Archiv für Protistenkunde 148(1-2): 65-76.

http://dx.doi.org/10.1016/S0003-9365(97)80037-1

Lange-Bertalot, H. \& Bonik, K. (1976) Massenentwicklung bisher seltener und unbekannter Diatomeen als Indikator starker Abwasserbelastung in Flüssen. Archiv für Hydrobiologie Supplement 49(3), Algological Studies 16: 303-332.

Round, F.E., Crawford, R.M. \& Mann, D.G. (1990) The Diatoms. Biology \& Morphology of the genera. Cambridge University Press, Cambridge. 747 pp.

Siver, P.A. \& Hamilton, P.B. (2011) Diatoms of North America. The freshwater flora of waterbodies on the Atlantic coastal plain. Iconographia Diatomologica 22: 1-916.

Siver, P.A., Hamilton, P.B. \& Morales, E.A. (2008) Brevilinea pocosinensis Siver, Hamilton \& Morales gen. et sp. nov., a new diatom (Bacillariophyceae) genus from North Carolina, USA. Phycological Research 56: 141-148.

http://dx.doi.org/10.1111/j.1440-1835.2008.00495.x

Taylor, J.C. \& Lange-Bertalot, H. (2006) Eolimna archibaldii spec. nov. and Navigiolum adamantiforme comb. nov. (Bacillariophyceae): two possibly endemic elements of the South African diatom flora tolerant to surface water pollution. African Journal of Aquatic Science 31(2): 175-183.

http://dx.doi.org/10.2989/16085910609503889

Tudesque, L., Rimet, F. \& Ector, L. (2008) A new taxon of the section Nitzschiae lanceolatae Grunow: Nitzschia costei sp. nov. compared to N. fonticola Grunow, N. macedonica Hustedt, N. tropica Hustedt and related species. Diatom Research 23(2): 483-501. http://dx.doi.org/10.1080/0269249X.2008.9705771

Van Dam, H., Mertens, A. \& Sinkeldam, J. (1994) A coded checklist and ecological indicator values of freshwater diatoms from The Netherlands. Netherlands Journal of Aquatic Ecology 28: $117-133$. 
Vyverman, W. (1991) Diatoms from Papua New Guinea. Bibliotheca Diatomologica 22: 1223, 208 pls. 
Figure captions

FIGURES 1-22. Brevilinea kevei sp. nov. LM: (Figs 1-10) from the Canal de Berry, France, (Figs 11-20) from the Kanyari Holt-Tisza, Hungary. Scale bar: $10 \mu \mathrm{m}$.

FIGURES 21-30. Brevilinea kevei sp. nov. EM: (Figs 21-24) from the Canal de Berry, France, (Figs 25-31) from the Kanyari Holt-Tisza, Hungary, SEM: Figs 21-23, 25-27 external view. SEM: Figs 24, 28 internal view; TEM: Figs 29-30. Scale bars: $2 \mu \mathrm{m}$ (Figs $21-$ 27, 29), and $1 \mu \mathrm{m}$ (Figs 28, 30). Holotype: Fig. 25; isotypes: Figs 26-30; paratypes: Figs $21-$ 24.

FIGURES 31-45. Fallacia indifferens. 31: Hustedt's (1942) original drawing with his numbers (27-30). LM images of the type material: Figs 32-41. Scale bar: $10 \mu \mathrm{m}$. SEM images from the type material. Figs 42, 44 external view, Figs 43, 45 internal view. Scale bars: $3 \mu \mathrm{m}$ (Figs 43-45) and $2 \mu \mathrm{m}$ (Fig. 42).

FIGURE 46. Distribution of the Brevilinea species. Black circle: type locality of $B$. pocosinensis. Black stars: the records of B. kevei. White star: type locality of B. kevei. 

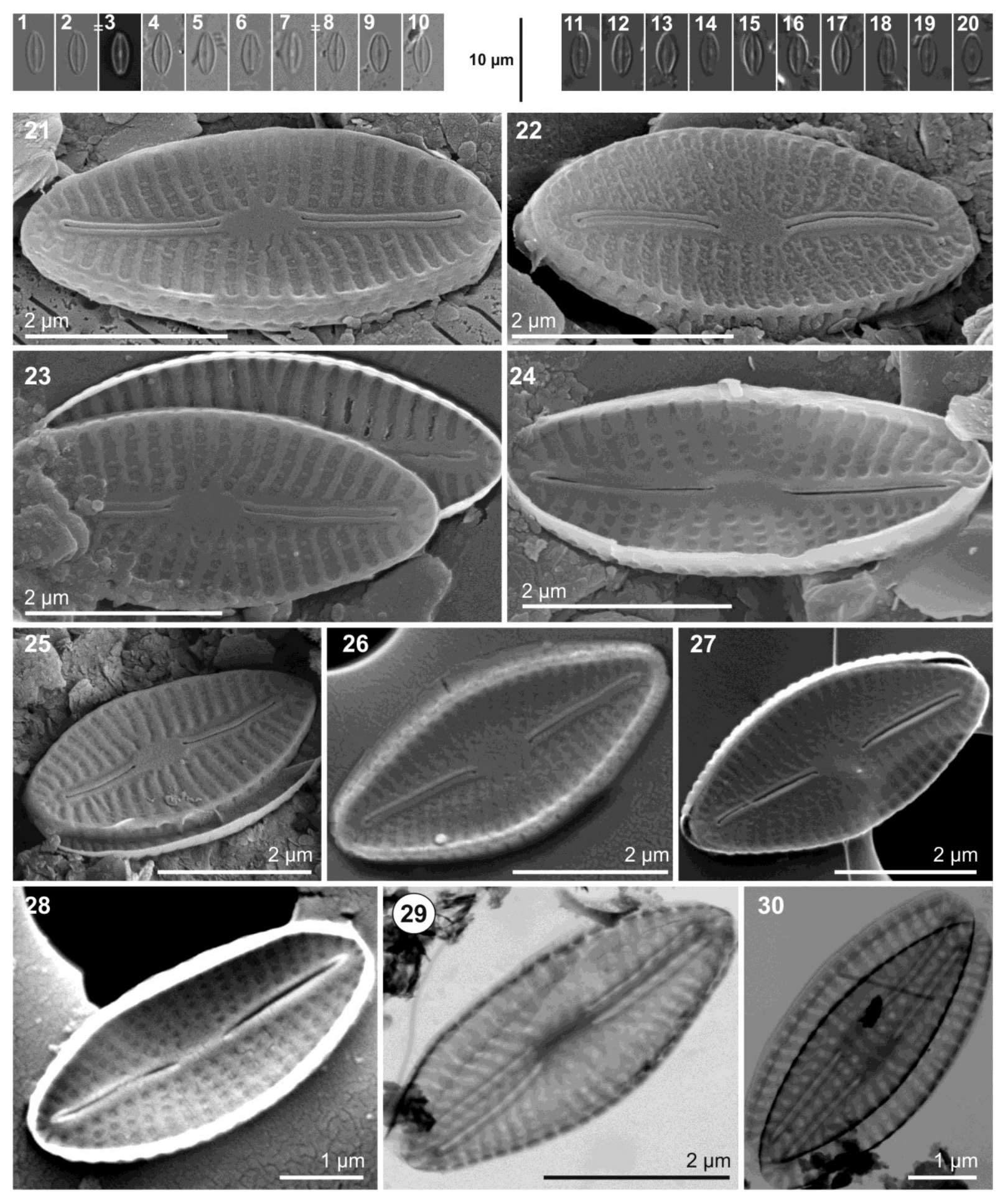


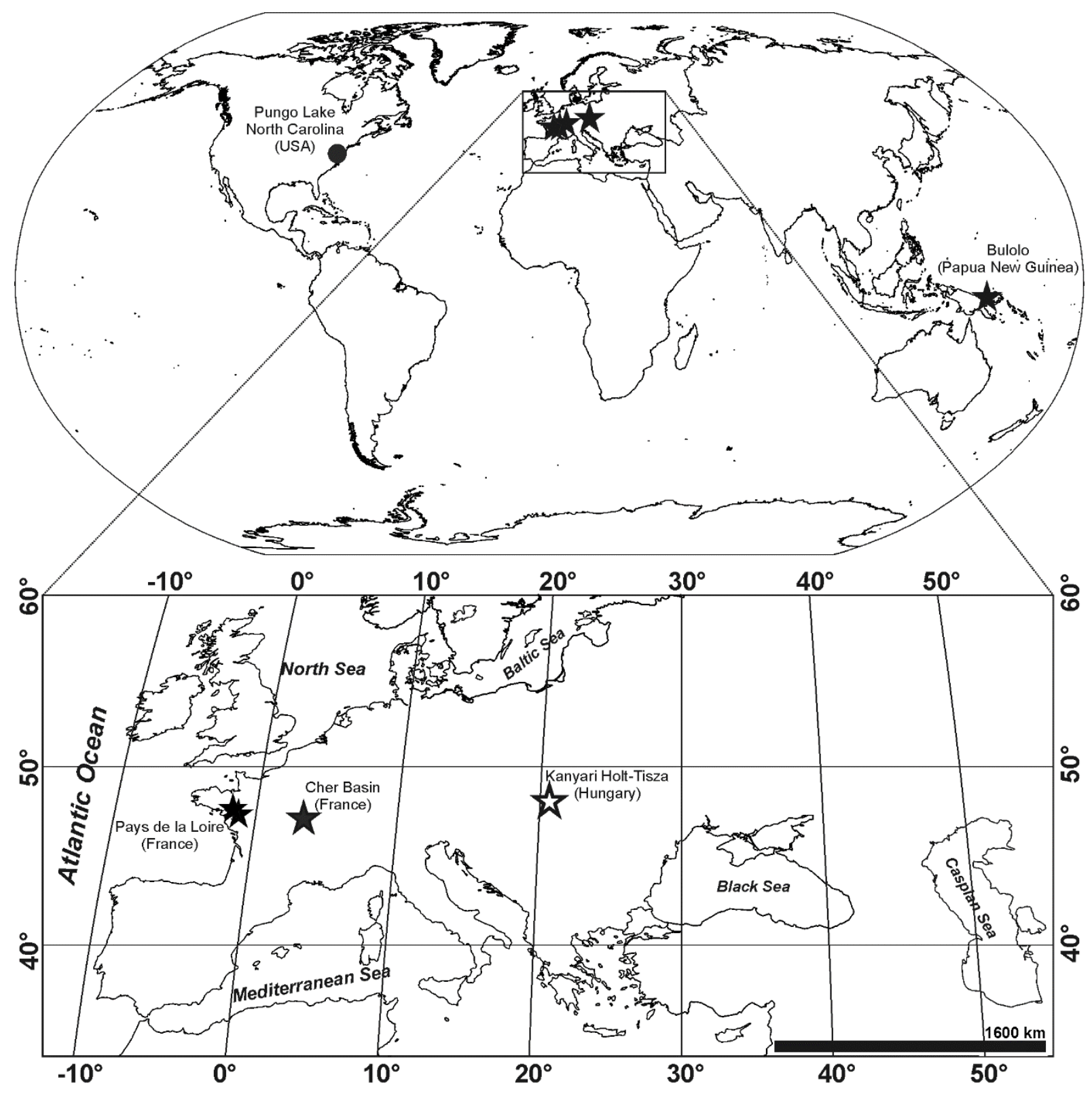



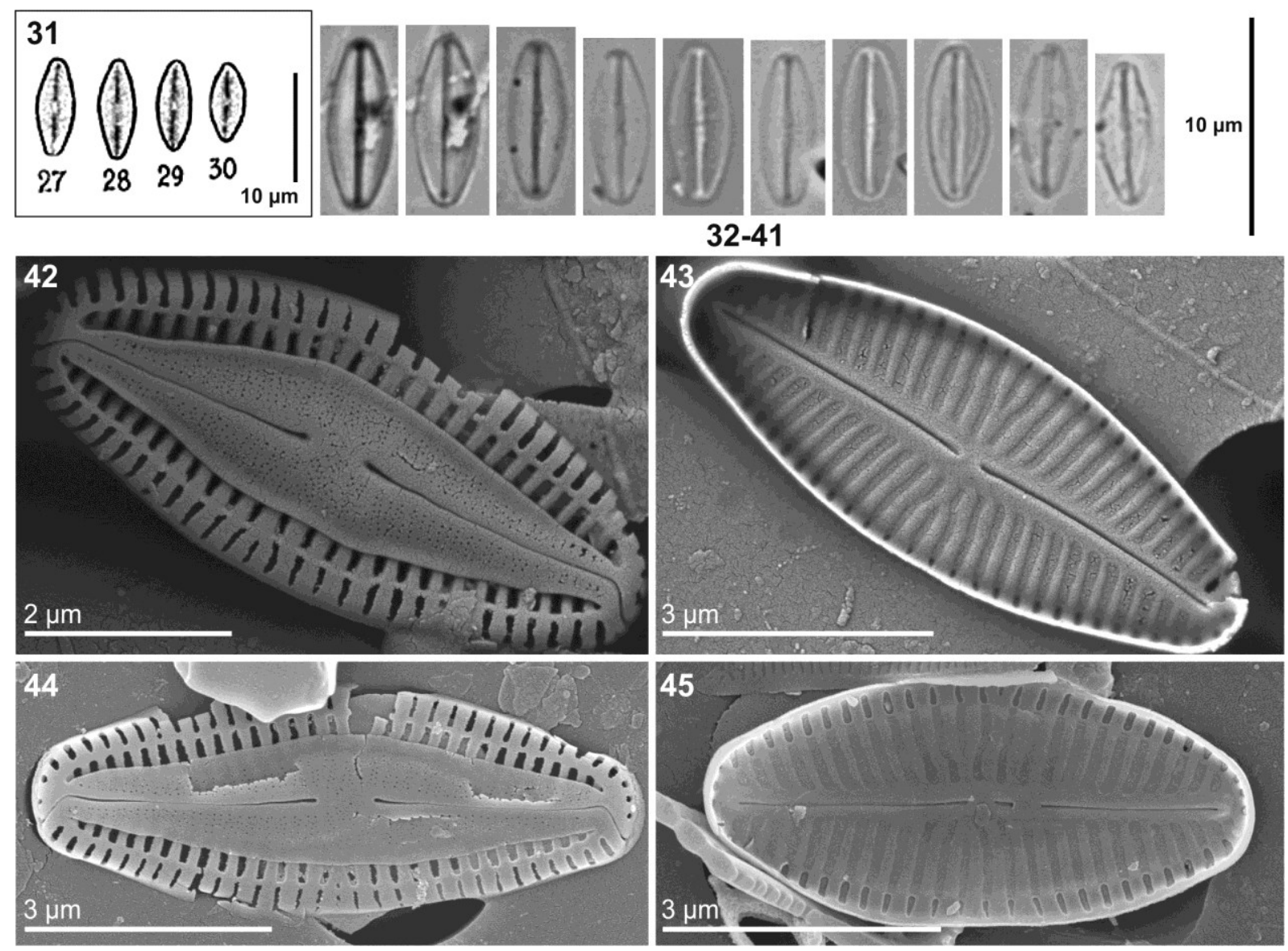